REVIEW ARTICLE

\title{
RNA Interference: A Novel Technology for Virus Disease Management in Crop Plants
}

\author{
Karthikeyan Gandhi ${ }^{1 *}$, Rajamanickam Suppaiah ${ }^{1}$, Suganyadevi Murugesan ${ }^{1}$ and Nagendran Krishnan ${ }^{2}$ \\ ${ }^{1}$ Department of Plant Pathology, Tamil Nadu Agricultural University, Coimbatore - 641003 \\ ${ }^{2}$ Division of Crop Protection, ICAR- Indian Institute of Vegetable Research, Varanasi - 221305
}

\begin{abstract}
RNAs play a significant role in regulating gene expression and their principal areas have been exploited for the control of plant viruses by the discovery of RNA silencing mechanism. RNA silencing or RNA interference (RNAi) is an innovative mechanism that regulates and restricts the amount of transcripts either by suppressing transcription (TGS) or by the degradation of sequence-specific RNA. RNAi can be used effectively to study the role of genes in a variety of eukaryotic organisms by reverse genetics. The technology has been employed in several fields such as drug resistance, therapeutics, development of genetically modified animals for research and transgenic plants targeting plant viruses. In plants, small interfering RNAs (siRNA) are the characteristic of 21 to 22 bp long dsRNA, which has been recognized by the regulatory mechanism of RNAi and leads to the sequence-specific degradation of target mRNA. In addition to virus disease control, RNAi can also be used to control mycotoxins and plant diseases caused by other organisms. This review enhances our current knowledge of RNAi and its larger applications in agriculture, specifically in plant virus disease management.
\end{abstract}

Keywords: RNAi; gene sources;Post-transcriptional gene silencing (PTGS);Silencing suppressors;VIGS

\section{INTRODUCTION}

Plant pathogens are a significant threat for the cultivation of crops and it creates difficulties in agriculture production, especially the plant viruses cause significant loss in the productivity of economically important crops around the world. The virus infection on crop plants causes $50-100 \%$ yield reduction depending upon the nature of crops and stages of virus infection. The complete yield loss was also noticed in several crops if it is infected during the early stages of infection and believed to cause one-third global loss of crop production. The strategies for viral disease management are based on agricultural practices, such as application of pesticides to manage the virus transmitting insect vectors, planting the fast-growing cereals as barrier crops to prevent insect movement, destroying the vulnerable weed hosts, and conserving optimal plant density to reduce disease incidence. However, they are rarely practiced under subsistence agriculture systems. In the past, traditional methods like use of cross protection and increased host plant resistance through beneficial microbes have been followed for virus disease management in several crops and that have worked markedly to some extent. Later, genes that are available naturally have been explored as one of the most effective sources to confer resistance

*Corresponding author's e-mail: agrikarthi2003@gmail.com in plants. However, only limited naturally available genes were explored to develop resistant varieties through molecular and breeding programmes (Sasaya et al., 2014). Though developing resistance in plants through conventional methods to protect them against viruses is expensive, it often takes years to breed resistance into desirable varieties. In order to sustain the agriculture production and maintain the quality produces, it demanded to use the biotechnological tools as one of the substantial techniques for the buildout of virus resistance in the plant to suppress the virus infection. The pioneering works on coat protein gene of Tobacco mosaic virus-mediated transgenic approach by Beachy (1986) opened up the perception of pathogenderived resistance. Later, advancements in genetic engineering and plant transformation increased the probability of developing multiple plant virus control strategies. There are two main approaches in engineering virus resistance in plants. The genes can be originated from the pathogenic virus itself (pathogenderived resistance) or from any other source (nonpathogen-derived resistance) (Dasgupta et al., 2003). In pathogen-derived resistance (PDR), a portion or full viral genome is inserted into a plant; thereafter, it regulates or interferes with vital steps in the life cycle of the pathogen, which led to resistance in plants against virus infection. Diverse viral pathogen$107 \mid 10-12$ | 1 
derived genes such as coat protein, movement protein and replicase genes have been effectively utilized to buildout the virus-resistant transformants (Baulcombe, 2002; Senthilraja et al., 2018; Gogoi et al., 2019).

\section{Importance of viral diseases on crop plants and their management}

The proper management of virus disease is fundamental to farmers and agricultural industries to meet the demands. The virus diseases in several crops cause huge losses in terms of quantity and quality of agriculture produces. For example, the genus Tospovirus is one of the key viral pathogens of plants found to be economically important by threatening vegetable production in India. Groundnut bud necrosis virus, a species of Tospovirus causes nearly 80 per cent crop loss in tomato and other Solanaceous crops under field conditions (Kunkalikar et al., 2010, 2011; Sushmitha and Bhat, 2014). Similarly, strains of Cassava mosaic virus cause more than 25 million tons of losses every year in Africa, India and Sri Lanka (Legg and Thresh, 2000). Tungro virus created epidemics during 2001 in West Bengal which resulted in loss of around 2911 million rupees (Muralidharan et al., 2003). The economic loss in rice due to virus diseases from South East Asia was estimated around more than $\$ 1.5$ billion (Abo and Sy, 1998; Sasaya et al., 2013). Sri Lankan cassava mosaic virus (SLCMV) belongs to the genus Begomovirus was found to be a severe pathogen of cassava causing mosaic disease in India and $84 \%$ yield losses has been documented in India (Thottapilly et al., 2003). Tobacco streak virus (TSV), which belongs to the genus llarvirus (Family, Bromoviridae), has an extensive host range which infects several vegetable crops causing heavy crop loss (Jain et al., 2005, 2008; Sivaprasad et al., 2010). In addition to vegetable crops, it infects groundnut (Reddy et al., 2002), sunflower (Ramiah et al., 2001), soybean (Arun Kumar et al., 2008), blackgram (Ladhalakshmi et al., 2006) and cotton (Jagtap et al., 2012; Vinodkumar et al., 2017) in India. Besides, economic loss in terms of yield is under estimated from the field in several crops due to virus infection because it requires precise diagnostic techniques to determine the damage caused due to pathogen. Recent trends in food security and intensive agriculture have fetched new tasks to fight against virus diseases. Disease control by means of curative measures i.e, adaptation of cultural practices, is impossible due to variability in genome of virus and obligate nature of pathogen. It is necessary to control the disease before establishing pathogen in crops using different approaches called a prophylactic measure. In this context, several researchers have identified the beneficial microbe to induce host plant resistance against virus infection in several crops. In addition, identification of new genes for developing the resistant plants through breeding programmes consumes more time and little laborious. It is necessary to apply advanced molecular biotechnological tools to develop genetically superior cultivars to suppress the virus disease in crop plants.

\section{Sources of gene to engineer the plants for virus resistance}

The rapid development in molecular biology techniques led to cloning and investigation of the genomic components of a variety of plant viruses. There are different strategies for transgenic resistance to plant virus.

1. Pathogen-derived resistance with the incorporation of pathogen components to the plant genome that interferes with the usual life cycle of the virus.

2. Pathogen-targeted resistance, relating to the inclusion of elements directly targeting viral genes and their products to make them nonfunctional.

3. Incorporation of prevailing genes from resistance plants into non-resistance plants.

Depending on the source of gene used, there are primarily two approaches for constructing genetically engineered resistance. The genes may be derived from the pathogenic virus itself (pathogen-derived resistance-PDR) or any other source. Non-pathogen-derived resistance involves using genes responsible for host tolerance and other genes regulating the adaptive host processes; genes provoked in response to pathogen attack to develop transgenics resistant to plant virus (Dasgupta et al., 2003). The approaches for PDR are classified into two groups, those that require the development of proteins (e.g., coat protein, replicase, movement protein-mediated resistance) and those that need only the viral nucleic acid accumulation (e.g., dsRNA-mediated resistance, sense, antisense, and ribozyme) (Kalantidis et al., 2002). In general, the earlier technique confer resistance to wide array of viruses, while the later provides high levels of resistance to a particular strain of virus. Several reports have been documented for the development of pathogen-derived virus resistance in plants. Enhancing the antiviral activity in plant species through gene silencing has proved to be effective in several plant-virus pathosystems.

\section{Coat protein-mediated resistance (CPMR)}

CPMR was first reported for Tobacco mosaic virus (TMV) in tobacco model system in 1986, and it has also been used to develop resistance to many viruses in various crop plants. CPMR may offer a broad range or narrow protection 
to transgenic plants. The TMC coat protein (CP) provides the resistance to closely associated strains of TMV effectively and fading levels of resistance to tobamoviruses which share low level of sequence similarities with CP gene was noticed (Nejidat and Beachy, 1990). The transgenic lines of Nicotiana benthamiana developed using CP of Cowpea aphidborne mosaic virus (CABMV) exhibited the delayed symptom development during the early stages of disease development (Mundembe et al., 2009). Raj et al. (2005) showed that transgenic tomato cv. Pusa Ruby developed using the CP gene of Tomato leaf curl virus (TLCV) exhibited variable degrees of resistance or tolerance when plants were challenge inoculated with viruliferous whiteflies carrying the TLCV. Later, the plants were found without symptoms even after 75 days of challenge inoculation. Further, PCR analysis using replicase gene-specific primers produced negative results in plants challenge inoculated and suggested that they did not support accumulation and replication of virus, indicating the CP gene (TLCV- CP) arbitrated the resistance in plants. Saker (2003) produced transgenic potato lines harbouring the CP gene of Potato virus Y (CP$P V Y$ ), and transgenic potato lines expressing $C P-P V Y$ gene, confers resistance against PVY.

\section{Movement protein-mediated resistance (MPMR)}

The cell-to-cell movement of virus in a plants system is mediated by movement proteins (MP). It has been shown that movement proteins change the gating mechanism of plasmodesmata, allowing the particle of virus and their derivatives to spread to neighboring cells. However, pathogenmediated resistance may also be engineered with dominant-negative mutant forms of viral genes. The usefulness of this strategy was demonstrated by the expression of viral MP in transgenic plants, that conferred resistance only when the transgene defined a dysfunctional MP. This phenomenon was first demonstrated in tobacco plants by producing modified MP to develop resistance against TMV, which is moderately active as a transgene. It is assumed that conferred resistance is based on the rivalry between the encoded MP gene of the wild-type virus and the preformed dysfunctional MP to bind to the plasmodesmatal sites (Lapidot et al., 1993). In addition, the above resistance was shown to be successful against distantly related or dissimilar viruses (Lapidot et al., 1993; Malyshenko et al., 1993). The transgenic N. benthamianaplants expressing the modified $13 \mathrm{~K} \mathrm{MP}$, determined by the central Triple Gene Block (TGB) ORF of White clover mosaic potexvirus (WCIMV), showed systemic resistance to WCIMV infection as well as expressed the resistance to Potato virus S (PVS) and two Potexviruses (Beck et al., 1994). Cooper et al. (1995) reported that transgenic $N$. tabacum cv. Xanthi NN lines express a gene encoding a dysfunctional MP (dMP+) of TMV that was developed with deletion of 3, 4 and $5 \mathrm{~N}$-proximal amino acids, which are known to be immune to many Tobamoviruses. The sign of disease and systemic spread of virus in the upper leaves of challenge inoculated plants were delayed the symptom expression and reduced the accumulation of virus as systemic infection in the plants challenge inoculated with Alfalfa mosaic alfamovirus, Cucumber mosaic virus, Tobacco ringspot virus, Tobacco rattle virus and Peanut chlorotic streak virus.

\section{Replicase protein-mediated resistance (Rep-MR)}

The replicase proteins conferred the immunity to infection by the virus, usually restricted to the strain of the virus, from which the target gene was derived. It was first demonstrated in transgenic plants containing a sequence that codes a replicase fragment of $54 \mathrm{kDa}$ against TMV (Golemboski et al., 1990). A truncated replicase gene derived from Cucumber mosaic virus (CMV) subgroup I has deliberated maximum level of resistance in transgenic tobacco against subgroup I of CMV strains. However, transgenes never showed any resistance to other subgroup II or other viruses (Zaitlin et al., 1994). Similarly, mutated replicationassociated protein from Maize streak virus (MSV) used for maize transformation showed stable expression and plants showed a substantial decrease in symptom severity (Shepherd et al., 2007). The mechanisms behind the suppression of virus was strongly believed to block the replication of virus and the protein formed by the transgene is proposed to interfere in some way with the replicase formed by the virus (Hellwald and Palukaitis, 1995; Heinlein, 2015; Lee et al., 2019).

\section{RNA silencing}

The RNAi-based strategies have been explored as a supremacy tool to engineer the plant against plant viruses. The resistance attained in transgenic plants mainly due to post-transcriptional gene silencing induced by transgene via dsRNA formation is termed as RNA silencing (Baulcombe, 2002). RNA silencing has augmented the search of plant antiviral mechanisms that enable down-regulation of gene expression with maximum accuracy without affecting the expression of other genes. The resistance targets precisely the RNA genome and it has been referred to as RNA mediated resistance / RNA interference (RNAi) (Wang et al., 2000; Grishok et al., 2000; Hammond et al., 2000; Smith et al., 2000). RNA interference mechanism was first demonstrated in plants, where insertion of additional copies of flower pigmentation responsible chalcone synthase gene resulted in the suppression of sequence-specific target and the endogenous RNA. Subsequently, 
transgenic lines were developed to produce reduced pigmentation in flowers or even the complete absence of pigmentation (Napoli et al., 1990; Van der Krol et al., 1990). RNAi can be induced in plants by delivering expression vectors similar to selfcomplementary dsRNA (Horiguchi, 2004; Watson et al., 2005) (Figure 1). Some experimental studies have revealed that inverted repeat constructs that encode hairpin RNAs (self-complementary RNAs) can induce RNA silencing effectively in plants and leads to high frequencies of resistance in transgenic lines (Chen et al., 2004). Helliwell and Waterhouse (2003) described that RNAi constructs have a spacer sequence between an inverted repeat and the resulting transcript from stem-loop structure from the RNAi construct and these transcripts are often called hairpin RNAs (hpRNAs). The increased gene silencing effect of constructs was attained by the existence of an intron in between the two complementary regions (Smith et al., 2000). They also demonstrated that plants transformed with a construct comprising sense and antisense sequences of Nla protease (Pro) gene of Potato virus $Y$ with flanking with the spacer fragment size of 800-nucleotide derived from the uidaA (GUS) gene expressed the high level of resistance to virus and conferred the stability of the seamless invertedrepeat sequences.

RNA silencing in plants can serve as defense mechanism against virus infection and transposons (Vance and Vaucheret, 2001; Voinnet, 2001). It has been shown that the expression of inverted repeats in transgenic plants improved the resistance against the virus, suggesting the role for double-stranded (ds) RNA. Since dsRNA is not a normal constituent of the eukaryotic cells and it became evident that they are the key regulator in the process of gene silencing mechanism, which leads to degradation of RNAs that are homologous in transgene (Vaucheret and Fagard, 2001). The DNA stability was formed by eliminating the loop region of hpRNA by replacing the spacer with an intron sequence, but was spliced out during pre-mRNA processing (Smith et al., 2000). The efficient silencing effect was documented in transformed plants expressing the inverted repeat constructs encompassing sense/anti-sense arms ranging from 98 to 853 nucleotide and inclusion of a spacer sequence (intron) in the constructs (Wesley et al., 2001). Tougou et al. (2006) also demonstrated the effect of inverted repeat construct containing CP gene of Soybean dwarf virus (SbDV) spaced by $\beta$-glucuronidase (GUS) sequences. The resultant transgenic soybean lines inoculated with SbDV remained symptomless, suggesting the involvement of RNA silencing in the resistance. In animals, delivery of sense or antisense RNA led to endogenous messenger RNA degradation (Guo and Kemphues, 1995). This type of revolution in animals was detected by the injection of dsRNA in Caenorhabditis elegans that resulted in endogenous mRNA degradation and it has been referred to as 'RNA interference' (RNAi) (Fire et al., 1998). Subsequently, the discovery of shorter forms of small RNA (siRNA) i.e. 25 nucleotides ( $\mathrm{nt}$ ),from the longer dsRNA has been considered as hall mark of RNA silencing (Hamilton and Baulcombe, 1999).



Figure 1. Schematic representation of RNAi mechanism in plants

\section{Coat Protein (CP)- based RNAi}

Pradeep et al. (2012) established that sunflower and tobacco transgenic lines that are expressed with inverted repeat-TSV CP gene showed the resistance to infection of TSV and lower levels of accumulation of TSV were observed compared with non-transgenic plants. Guo et al. (2015) developed the transgenic sugarcane expressing CP gene of Sorghum mosaic virus (SrMV) based on the RNA silencing approach. It was reported that transgenic line expressing the RNA cassettes showed resistance against SrMV upon artificial inoculation. Similarly, tobacco plants transformed with hpRNA containing CP gene of TSV through the Agrobacterium, mediated

$107 \mid 10-12$ | 4 
Table 1. RNAi mediated resistance in plants against virus diseases

\begin{tabular}{|c|c|c|c|}
\hline Crop & Virus & $\begin{array}{l}\text { Gene used for } \\
\text { resistance }\end{array}$ & Reference \\
\hline Tobbaco / rice & Potato virus Y (PVY) & Protease (Pro) gene & Waterhouse et al. (1998) \\
\hline Tobacco & Cotton leaf curl virus (CLCuV) & AC1 double-stranded RNA & Asad et al. (2003) \\
\hline Arabidopsis thaliana & Turnip mosaic virus (TuMV) & Coat protein & Nomura et al. (2004) \\
\hline Tomato & Tomato yellow leaf curl virus (TYLCV) & $A C 1$ double-stranded RNA & Yang et al. (2004) \\
\hline Papaya & Papaya ringspot virus W (PRSV-W) & Coat protein & $\begin{array}{l}\text { Krubphachaya et al. } \\
(2007)\end{array}$ \\
\hline Soybean & Soybean dwarf virus (SbDV) & Coat protein & Tougou et al. (2006) \\
\hline Tobacco & $\begin{array}{l}\text { Cucumber green mottle mosaic virus } \\
\text { (CGMMV) }\end{array}$ & Coat protein & Kamachi et al. (2007) \\
\hline Groundnut & Tobacco streak virus (TSV) & Coat protein & Bag et al. (2007) \\
\hline Tomato & Tomato leaf curl virus (ToLCV) & Replicase & Ramesh et al. (2007) \\
\hline Common Bean & Bean golden mosaic virus (BGMV) & Replicase & Bonfim et al. (2007) \\
\hline Rice & Rice tungro bacilliform virus (RTBV) & DNA encoding ORF IV & Tyagi et al. (2008) \\
\hline Tobacco & Potato virus $Y(\mathrm{PVY})$ & Coat protein & Vargas et al. (2008) \\
\hline Lettuce & Mirafiori lettuce virus(MiLV) & Coat protein & Kawazu et al. (2009) \\
\hline Cassava & $\begin{array}{l}\text { Cassava brown streak Uganda virus } \\
\text { (CBSUV) }\end{array}$ & Coat protein & Yadav et al. (2011) \\
\hline Tobacco & Tobacco streak virus (TSV) & Coat protein & Pradeep et al. (2012) \\
\hline Banana & Banana bunchy top virus (BBTV) & Replicase & Elayabalan et al. (2013) \\
\hline Tomato & Cucumber mosaic virus (CMV) & Replicase & Ntui et al. (2014) \\
\hline Tobacco & Tobacco streak virus (TSV) & Coat protein & $\begin{array}{l}\text { Rajamanickam et al. } \\
\text { (2015a) }\end{array}$ \\
\hline Tobacco & Tobacco streak virus (TSV) & Replicase & $\begin{array}{l}\text { Rajamanickam et al. } \\
(2015 b)\end{array}$ \\
\hline Rice & Rice stripe virus (RSV) & Coat protein & Li et al. (2016) \\
\hline Banana & Banana bunchy top virus (BBTV) & Replicase & Elayabalan et al. (2017) \\
\hline Groundnut & Tobacco streak virus (TSV) & Coat protein & Senthilraja et al. (2018) \\
\hline Cassava & $\begin{array}{l}\text { South African cassava mosaic virus } \\
\text { (SACMV) }\end{array}$ & Replicase & Walsh et al. (2019) \\
\hline Tobacco & Srilankan cassava mosaic virus (SLCMV) & Coat protein & Gogoi et al. (2019) \\
\hline Tomato & Groundnut bud necrosis virus (GBNV) & $\begin{array}{l}\text { Coat protein, Replicase } \\
\text { protein }\end{array}$ & Suganyadevi (2019) \\
\hline
\end{tabular}

transformation exhibited resistance to TSV upon mechanical inoculation and ELISA confirmed the lower level of virus titre in transgenic tobacco lines (Rajamanickam et al., 2015a). Gogoi et al. (2019) found that transgenic tobacco plant expressing sense and antisense orientation of CP gene of Sri Lankan cassava mosaic virus (SLCMV) showed resistance to SLCMV. The Northern blot analysis of tobacco line confirmed the expression of virus specific siRNAs, indicated that RNA silencing technology has been adopted in virus resistance.
Jia et al. (2017) developed the transgenic lines that are expressed with CP gene of Papaya ringspot virus (PRSV) showed a wide spectrum of resistance against PRSV I, II and III subgroup and Northern blot analysis the production of siRNA in transgenic lines confirms the RNA interference. Senthilraja et al. (2018) investigated the development of transgenic peanuts by expressing the hpRNA cassettes containing CP gene of TSV through Agrobacterium-mediated transformation. The developed transgenic line showed resistance against TSV upon sap inoculation 
under greenhouse conditions, which suggested that the resistance in peanut plants against TSV was induced through genetic manipulation by expressing dsRNA of CP gene of TSV as marker for RNAi. Chen et al. (2019) found that chimeric hpRNA comprising $\mathrm{CP}$ genes of Cymbidium mosaic virus (CymMV) and Odontoglossum ringspot virus (ORSV) expressed in tobacco showed normal growth and produced no symptoms when inoculated with CymMV and ORSV as mixed inoculum, which conferred the RNA mediated interference.

\section{Movement Protein (MP) based RNAi}

The MP gene of several viruses has been demonstrated to be the useful gene to suppress the disease in transgenic plants. For example, RNA interference-based gene construct containing part of movement protein gene derived from Chickpea chlorotic dwarf Pakistan virus (CpCDPKV) expressed in $N$. benthamiana showed the optimistic resistance against CpCDPKV (Nahid et al., 2011). Similarly, transgenic tobacco lines expressed with hpRNA comprising MP gene of Tobacco mosaic virus (TMV) exhibited comprehensive resistance to TMV. Furthermost, high level of TMV replication was observed in all the tobacco control plants, whereas an undetectable level of TMV multiplication was observed in transgenic plants challenged with CMV and TMV (Hu et al., 2011). The artificial miRNA169a consisting of 21 nucleotides derived from V2 gene (movement protein) region of Cotton leaf curl Burewala virus (CLCuBuV) transformed in cotton showed partial resistance against CLCuBuV and artificial inoculation of transgenic lines showed complete resistance against Cotton leaf curl Kokhran virus (CLCuKoV).

Further analysis revealed the possibility of RNAmediated resistance in transgenic cotton (Ali et al., 2013). Ntui et al. (2015) revelated that cassavatransgenic lines expressing the dsRNA derived from part of AV2 and AV1 (movement protein) of Sri Lankan cassava mosaic virus (SLCMV) showed high level of resistance against SLCMV. The Northern blot analysis confirmed the presence of siRNA specific to target gene of SLCMV, indicated the RNA silencing mediated resistance. Similarly, double-strand RNA derived from movement protein gene of Sesbania mosaic virus (SeMV) showed resistance in Sesbania plants against SeMV and MP gene-derived dsRNA provided higher level of resistance compared to dsRNA derived from CP gene. The sequence specific target conferred the resistance mechanisms in Sesbania, which indicated the RNA silencing mediated resistance (Konakalla et al., 2019).

\section{Replicase based RNAi}

The transgenic tobacco plants expressed with hpRNA containing the part of replicase gene of
Chickpea chlorotic dwarf Pakistan virus (CpCDPKV) impaired the symptom expression of CpCDPKV and real-time PCR analysis confirmed the lower level of virus titre in transgenic lines (Nahid et al., 2011). Shekhawat et al. (2012) developed the transgenic banana expressing the intron-hpRNA comprised with replication initiation protein (Rep) of Banana bunchy top virus (BBTV). The transgenic lines were resistant to BBTV and siRNA analysis confirms the mechanism based on RNA interference. Elayabalan et al. (2013) developed transgenic banana plants expressing the replicase gene of banana bunchy top virus (BBTV) through Agrobacterium-mediated transformation. Transgenic lines expressing RNAirep gene construct showed resistance to BBTV; symptomless and suppressed level of replication of virus was also observed. Jada et al. (2014) found that full-length expression of TMV in tobacco plants showed resistance against TMV and expressed the multiple defense mechanisms, including the presence of reduced level of viral replication in virus challenged transgenic lines. Peng et al. (2014) found that transgenic tobacco harboring hpRNA derived from RNA dependent RNA polymerase of Watermelon silver mottle virus (WSMoV) exhibited the broad-spectrum resistance against different Tospoviruses like Groundnut yellow spot virus, Groundnut chlorotic fan spot virus, Impatiens necrotic spot virus and Tomato spotted wilt virus.

Similarly, transgenic tomato expressing the same construct showed resistance against WSMoV and other Tospoviruses. The tobacco plants transformed with hpRNA containing replicase gene of TSV through thetransformation mediated by Agrobacterium exhibited resistance to TSV upon mechanical inoculation and ELISA confirmed the lower level of virus titre in transgenic tobacco lines (Rajamanickam et al., 2015b). The squash plants expressing the hpRNA construct derived from replicase gene of Squash leaf curl virus (SqLCV) showed resistance against SqLCV. Further, qPCR analysis confirmed reduction in virus accumulation of virus genome in transgenic plants (Taha et al., 2016). Elayabalan et al. (2017) developed the RNAi gene construct corresponding to replicase gene of banana bunchy top virus (BBTV). The banana cv. Virupakshi (AAB) plants injected with Agrobacterium-containing construct did not produce any symptoms of BBTV after 45 days of infection whereas, non-injected plants have produced the symptoms, suggested the RNA mediated resistance.Suganyadevi et al. (2019) developed the hpRNA construct corresponding to replicase gene of groundnut bud necrosis virus (GBNV). The tomato cv. PKM1 injected with Agrobacterium containing construct through inplanta transformation technique did not produce any symptoms, whereas non-transgenic plants produced the symptoms.

$107 \mid 10-12$ | 6 
Table 2. List of viral proteins act as suppressors

\begin{tabular}{|c|c|c|c|c|c|c|}
\hline S. No & Virus & Genus & Genome & $\begin{array}{c}\text { Viral } \\
\text { proteins }\end{array}$ & Mechanism of action & Reference \\
\hline 1. & Tobacco streak virus & Ilarvirus & RNA & $2 b$ & - & Valentine et al. (2004) \\
\hline 2. & Cucumber Mosaic Virus & Cucumovirus & RNA & $2 b$ & - & Duan et al. (2012) \\
\hline 3. & Citrus leaf blotch virus & Citrivirus & RNA & MP & - & Renovell et al. (2012) \\
\hline 4. & Tomato spotted wilt virus & Tospovirus & RNA & NSs & $\begin{array}{l}\text { Sequesters both long dsRNA } \\
\text { and double-stranded siRNA } \\
\text { or miRNA }\end{array}$ & $\begin{array}{l}\text { Schnettler et al. } \\
(2010)\end{array}$ \\
\hline 5. & Beet yellows virus & & RNA & P21 & Sequesters siRNA duplexes & Ye and Patel (2005) \\
\hline 6. & Citrus tristeza virus & Closterovirus & RNA & $\begin{array}{l}\text { p23, capsid } \\
\text { protein, p20 }\end{array}$ & - & Lu et al. (2004) \\
\hline 7. & $\begin{array}{l}\text { Sweet potato chlorotic stunt } \\
\text { virus, Tomato chlorosis virus }\end{array}$ & Crininvirus & RNA & P22 & Sequesters siRNA duplexes & Kataya et al. (2009) \\
\hline 8. & Beet western yellow virus & Polerovirus & RNA & PO protein & Targets AG01 to degradation & Csorba et al. (2010) \\
\hline 9. & Pea enation mosaic virus & & RNA & PO protein & Targets AG01 to degradation & Fusaro et al. (2012) \\
\hline 10. & Wheat streak mosaic virus & Tritimovirus & RNA & P1 Protein & - & Young et al. (2012) \\
\hline 11. & Rice stripe virus & Tenuivirus & RNA & NS3 & Sequesters siRNA duplexes & - \\
\hline 12. & Red clover necrotic virus & Dianthovirus & RNA & MP & - & \\
\hline 13. & Turnip yellow mosaic virus & Tymovirus & RNA & P69 & - & Chen et al. (2004) \\
\hline 14. & Tobacco mosaic virus & Tobamovirus & RNA & $\begin{array}{l}\text { Small } \\
\text { replicase } \\
\text { subunit }\end{array}$ & & Vogler et al. (2007) \\
\hline 15. & Tomato yellow leaf curl virus & Begomovirus & DNA & $\mathrm{C} 4$ & Sequesters siRNA duplexes & Luna et al. (2012) \\
\hline 16. & Mungbean yellow mosaic virus & & DNA & TrAP / AC2 & - & Trinks et al. (2005) \\
\hline 17. & Banana bunchy top virus & Babuvirus & DNA & Clink, MP & - & Niu et al. (2009) \\
\hline
\end{tabular}

\section{Applications of RNAi}

RNA interference is a useful reverse genetic technology for evaluating gene functions in a variety of species and organisms. It has been first adopted to determine the role of chromosome I and II of Caenorhabditis elegans through gene knockout techniques. The study identified the role of these genes involved in embryonic development and cell division in C. elegans (Fraser et al., 2000; Gonczy et al., 2000). Similarly, the production of decaffeinated coffee plants was developed by knocking down the theobromine synthase gene using hairpin constructs (Ogita et al., 2003). In addition, RNAi is useful in multipurpose applications like disease control in crops, specifically the viruses, treatment of tumorsin medical application, control of bacterial and parasites in the medical industry, drug development and production of model animal for research (Pereira and Cendes, 2013). RNAi can promote the screening and production of drugs by discovering genes that can impart drug resistance or genes whose mutantphenotypes area meliorated by drug therapy, providing information on modes of action of new compounds.Itwas also a preferred method of application to investigate the concurrent functions of multiple genes expressing the functions in organisms, where duplication occurs concerning a specific function, as many of these genes may be silenced simultaneously. The polymer and lipidnanoparticles-based delivery of siRNA was effective in delivering the siRNA into the human body that facilitates the broad translational success of RNA interference (RNAi) technology in therapeutic applications (Pottash et al., 2019).

The gene silencing effect was first detected in petunia plants through the delivery of exogenous transgenes to up-regulate the activity of the chalcone synthase gene, an enzyme involved in the development of particular pigments (Napoli et al., 1990). The incorporation of transgene resulted in the production of variegation with complete loss of color. This might be due to the introduced homologous DNA sequence, which indicated the possible mechanism of suppression of endogenous loci and the phenomenon was called as "cosuppression"(Hannon, 2002). Later, the technology 
was instrumental in agriculture for crop development and enhanced plant nutritional value (Abdolhamid et al., 2010). The RNAi technology can also be used effectively to improveseed germination and nutritional quality in plants. A high-lysine maize variant has been developed by knocking out the expression of the 22-kD maize zein storage protein (Segal et al., 2003). The myo-inositol-3-phosphate synthase (MIPS1) gene from soybean is involved in phytic acid (PA) biosynthesis. PA is the major phosphorus reserve material in soybean seeds and it is a potent iron chelator, causing deficiencies that lead to malnutrition. The disrupted MIPS1 gene through RNAi approach, limiting the enzyme PA biosynthesis in soybean seeds, leads to improved quality of seed with more of minerals (Kumar et al., 2019). RNA-induced silencing technology has become one of the favored methods for inducing resistance to viruses in plants. RNAi has been exploited for the management of several plant viruses in agriculture crops. Tobacco plant expressing coat protein and replicase genes of TSV showed resistance against TSV through RNAi mediated resistance mechanism (Rajamanickam et al., 2015a,b). Cowpea plant employed with RNA silencing technology by expressing transcriptional activator protein AC2 (TrAP) has shown resistance against Mungbean yellow mosaic India virus (MYMIV) (Kumar et al., 2017). The chimeric gene construct containing $\mathrm{CP}$ and silencing suppressor genes of Cucumber mosaic virus (CMV) and the Potato virus $Y$ (PVY) expressed in the tobacco plant exhibited more siRNA than the construct containing a single hairpin structure. The transgenic tobacco plants showed resistance against mixed infection of CMV and PVY (Xie et al., 2014). The genes from viral genomes used to develop transgenic plants to manage the virus diseases are appended in table 1.

\section{Post-transcriptional gene silencing (PTGS)}

Post-transcriptional gene silencing can be achieved either by degradation of transcripts or by translational inhibition by siRNAs. Most of the research carried out in Arabidopsis thaliana indicates signal as directed by small interfering RNAs (Xie et al., 2004). In plants, RNA silencing pathways are greatly classified based on their functional requirements (Baulcombe, 2004; Meister and Tuschl, 2004). There are four pathways viz., micro RNA (miRNA) pathway, small interfering RNA pathway, RNA directed DNA methylation pathway and exogenic RNA silencing pathway. The concept of RNAi first came into the limelight of the world by the discovery of the role of purified dsRNA injected into the body of Caenorhabditis elegans (Fire et al., 1998). After injection of dsRNA, which corresponds to the nucleotide segment of unc22 encoded for a non-essential myofilament protein into an adult nematode, corresponding decreased activity leads to severe twitching phenotype was noticed, dsRNA injected nematode showed weak twitching, where progenies were also strong twitchers. Drosophila embryo extracts has been well studied for the biochemistry of RNA silencing and recorded with a two-step reaction viz., initiation and effector phases. During the initiation step, longer dsRNA molecules are converted into siRNA or miRNA species. Small RNAs characteristic with the size of 21-26 bp contain 2 nt 3'-overhangs and 5'- phosphorylated termini formed by RNase-III-type enzymes from the Dicer protein family (Bernstein et al., 2001). The molecules of siRNA and miRNA are distinct in their origin and structure, The miRNA molecules are host- encoded and derived from long single stranded (ss) RNAs(Bartel, 2004). During effector phase, one strand of the siRNA or miRNA duplex is loaded onto a ribonucleoprotein complex, the RNA induced silencing complex (RISC) for sequence specific identification of target RNAs (Schwarz et al., 2003; Tomari and Zamore, 2005). Viruses can be the source, the target, or both the source and the target of silencing. Virus-mediated post-transcriptional gene silencing (PTGS) can occur with RNA viruses which can replicate in the cytoplasm and also for DNA, which replicate in the nucleus (English et al., 1996). Generally, sense and antisense components of transgenes were separated by an intron to increase the efficiency of PTGS (Smith et al., 2000). The component involved in the RNA silencing mechanism are dicer which belongs to the RNase III family, Argonaute2 protein, RNA and DNA helicases, translation initiation factor, RNA- dependent RNA polymerase and transmembrane protein as channel or receptor.

Enzymatic behavior of the members of the Argonaute (AGO) protein family assists the programmed RISC to divide complementary mRNAs or arrest their translation (Fagard and Vaucheret, 2000; Hammond et al., 2000). In plants and animals, molecular and genetic research has discovered multiple pathways of RNA silencing where various small RNAs and RNA silencing proteins play a major role. The next big step in this silencing method is separating dsRNA into small dsRNA fragments, called dicer (Bernstein et al., 2001). These short sequences of unique RNAs of 21-25 nucleotides are detectable in all cells where PTGS is involved (Hamilton and Baulcombe, 1999). The shorter dsRNAs are often referred to as "short interfering RNAs" because they constitute an intermediate that can trigger the silencing process. The siRNAs will be integrated into the RNA-inducing silence complex (RISC) induced with RNA (Hammond et al., 2000), which is the actual sequence-specific endoribonuclease that cleaves single-stranded target RNA. 
Table 3. List of viruses to develop VIGS vectors

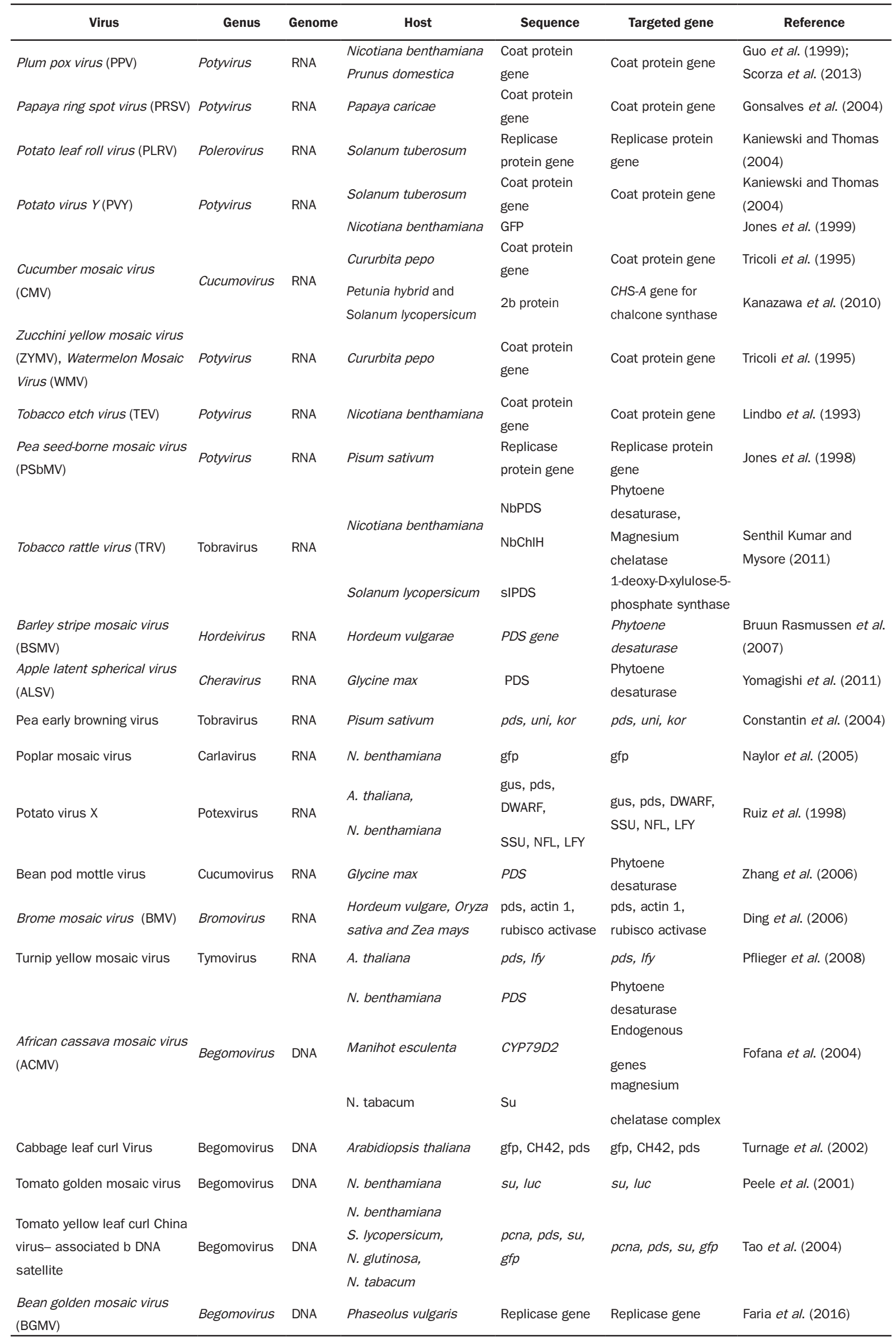


RNAi can be caused in plants by the application of expression vectors that transcribes a selfcomplementary dsRNA (Horiguchi, 2004; Watson et al., 2005). Several studies have shown that inverted repeat construct encodes self-complementary RNAs (hairpin RNAs) and effectively induced RNA silencing, leading to high resistance in transgenic plants (Smith et al., 2000; Chen et al., 2004). In transgenic plants, gene silencing can be achieved with constructs that express self-complementary RNA containing sequences homologous to the target genes (Helliwell and Waterhouse, 2003). These RNAi constructs include a series of spacers between an inverted repeat and the corresponding transcript from the stem-loop structure of the RNAi construct. These transcripts are thus sometimes referred to as hairpin RNAs (hpRNAs). Spacer sequence in the vector allows stable replication of RNAi plasmids in E. coli (Lee and Carthew, 2003). pHANNIBAL and pKANNIBAL with bacterial ampicillin and kanamycinresistant genes, respectively, were designed by Wesley et al. (2001). For the development of hairpinRNA (hpRNA), a loop of 30-50 bases depending on various restriction sites were used to insert targeting gene sequences. In addition, it has been reported that the hpRNA constructs containing sense/anti-sense arms range from 98 to 853 nucleotides gave efficient silencing in a wide range of plant species and inclusion of an intron in these constructs had a consistently enhancing effect. The degree of silencing was observed 90-100\% greater than that obtained in either co-suppression or antisense constructs. The presence of intron in between two complementary regions enhances silencing efficiency (Smith et al., 2000).

\section{Suppression of gene silencing}

RNA silencing is a conserved eukaryotic event in the eukaryotic pathway that involves clampdown of specific gene expression facilitated by $21-24 n t$ siRNA. Previously, an antiviral function of RNA silencing in a transgenic plant after infection with a potyvirus was demonstrated through molecular analysis (Lindbo et al., 1993). Antiviral function explained the accumulation of siRNAs which are derived during viral infection at high level. Symptoms were appeared in the infected plants, and later, plants were recovered from the infection and become resistant to ensuing infection with the same virus. More studies reported and supported this model (Table 2). To counteract on RNAi antiviral defense, viruses from all the genera encoded for viral suppressors of RNA silencing. It inhibits major steps of RNAi system. Viral suppressing pathways primarily inhibit the siRNA biogenesis by preventing the recognition of SiRNA by the AGO effector, RNAinduced silencing complex, and enzymes responsible for DNA-methylation in the host.

\section{Suppression of RNA silencing through viral suppressors}

\section{A) Inhibiting viral RNA sensing and dicing}

Two viral proteins like P14 of Pothos latent aureusvirus and P38 of Turnip crinkle virus bind with dsRNA in a size-independent way (Merai et al., 2005, 2006). It has been shown that P38 inhibits the DCL4 in the Arabidopisis (Deleris et al., 2006). P38 protein interferes with AG01 binding, which leads to inhibition of DCLS (Azevedo et al., 2010). In Cauliflower mosaic virus (CaMV), P6 has been shown as viral translational trans-activator protein for virus-derived small interfering RNAs (vsiRNA). P6 protein was recorded as RNA silencing suppressor and it binds with dsRNA, which has been required for the functioning of DCL4 (Haas et al., 2008).

\section{B) Inhibiting the RNA induced silencing complex (RISC)}

Viral suppressor of RNA silencing can prevent RISC complex. They can accomplish target AGO proteins, siRNAs and miRNAs in a wide variety of mechanisms. Among the various suppression activities, the most common strategy is dsRNA suppression, which stops the assembly of the RISC effector (Lakatos et al., 2006; Csorba et al., 2007, 2010; Wu et al., 2010). The P19 protein is the best-known viral suppressor of RNA silencing (VSRs) in tombusviruses, which binds with ds siRNA having high affinity (Vargason et al., 2003). For all biogenesis processes of siRNAs and miRNAs, 2'-O methylation step is highly essential. Viral protein viz., HC-Pro gene of Tobacco etch virus, P122/130 of Tobamovirus and $\mathrm{P} 19$ of Carnation Italian ringspot virus involves in preventing si/miRNA RISC assembly (Vogler et al., 2007; Lozsa et al., 2008; Yu et al., 2006). During the suppression process by the VSRs, siRNA is sequestered and its binding is inactivated before incorporation into RISC complex resulted in the spread of viral infection in the plants.

\section{C) Inhibitingthe AGO protein}

Assembly of RISC complex has been prevented directly or indirectly by interactions of RISC complex and VSRs (Burgyan and Havelda, 2011). In Cucumber mosaic virus (CMV), The $2 \mathrm{~b}$ protein prevented the proliferation of long-range signal, which facilitates systemic infection of virus (Guo and Ding, 2002). Additionally, CMV 2b protein interacts with the PAZ domain and inhibits the slicing activity of AG011 (Zhang et al., 2006) and co-localized in the nucleus of the cell (Mayers et al., 2000). Tomato aspermy virus (TAV), $2 \mathrm{~b}$ protein binds with long dsRNA and inhibits the synthesis of viral secondary siRNAs (Diaz Pendon et al., 2007). It is concluded that $2 \mathrm{~b}$ protein has dual role in either by concealed siRNA or by relating with AGO1 and foiling the 
assembly of RISC complex. Similarly, the PO protein of poleroviruses has also been involved in targeting the essentialactivities of RISC complex and AGO protein, resulted in suppression of RNA silencing through induced degradation (Baumberger et al., 2007; Bortolamiol et al., 2007).

\section{Virus-induced gene silencing}

Virus-induced gene silencing (VIGS) has been considered as a mechanism demonstrated with the homology-dependent degradation of RNA via plant-virus-derived vectors carrying endogenous gene sequences. Without the need for genetic transformation in plants, VIGS has been explored as an effective tool for reverse genetics and developed to evaluate the gene functions in various plant species. VIGS's success is due to five factors,

1. Methodology is simple and frequently involved with agroinfiltration or biolistic inoculation.

2. The results are attained within short period of time i.e., some weeks after inoculation.

3. The tool avoids the transformation process and applicable to a greater or a wide variety of plants.

4. It shows the potential to silence several genes and

5. Can be used for forward and reverse genetics (Senthil Kumar and Mysore, 2011).

6. VIGS was first described as the mechanism of retrieval from virus diseased plants. Now the term VIGS is analogous to the process of knock-down expression of endogenous genes by a recombinant viral vector.VIGS is based on RNA interference (RNAi), which refers to gene expression interference mediated in a sequence-specific manner by tiny RNA. Pathway manifestations are referred to in plants as Post Transcriptional Gene Silencing (PTGS) (Lindbo et al., 1993; Soosaar et al., 2005), RNAi in animals (Fire et al., 1998) and Quelling in fungi (Cogoni et al., 1996). To develop the VIGS vectors, several RNA and DNA genomes have been used (Table 3) (Burch-Smith et al., 2004). VIGS have been reported in both monocot like barley, wheat, rice, maize, ginger and banana and also in dicot plants like Eschscholzia californica, Aquilegia vulgaris, Papaver somniferumand Thalictrum species. Several viral vectors were obtained from positive-strand RNA viruses, which include TMV, Potato virus $X$ and Tobacco rattle virus (Lange et al., 2013) and DNA virus, like African cassava mosaic virus (ACMV) (Fofana et al., 2004). For agro-inoculation, VIGS vectors were derived using a cDNA copy of the viral genome that is inserted into the binary vector and translated into the $A$. tumefaciens strain.

\section{Mechanism of virus-induced gene silencing}

VIGS is focused on the ability of plant viruses to activate a PTGS-related plant defense mechanism. Post-transcriptional gene silencing is activated by the perception of dsRNA. Both RNA and DNA viruses, during their genome expression or replication, a viral double-stranded RNA can be produced from various sources:

1. Transcriptions of DNA viruses cause RNA transcripts to overlap (Ding and Voinnet, 2007)

2. By cellular or viral RNA dependent RNA polymerase, viral ssRNA converted into dsRNA (Lu et al., 2003)

3. Through intra-molecular base pairing, hairpin dsRNA (Molnar et al., 2005).

RNA interference mechanism is a phenomenon in which small dsRNA evades the expression of targeted genes through the sequence-specific degradation of mRNA. VIGS is one of the approaches to studying the specific gene function in plants. RNA viruses produce dsRNA during the multiplication in the host by the action of virus-encoded RdRP. The TRV3 genome of Tobacco rattle virus modified to carry with target gene and agroinfiltration in three weeks old tobacco plants induced the silencing of sequence-specific target in newly emerging leaves confirms the VIGS mechanism (Senthil Kumar and Mysore, 2014). Similarly, VIGS target gene in sense and antisense orientations into the Tobacco ringspot virus by mutating the sequence following the CP stop codon for the transient expression of foreign genes. The VIGS of phytoene desaturase (PDS) in N. benthamiana lead to the development of noticeable photo-bleaching phenotypes (Zhao et al., 2016). The viruses used to develop VIGS vectors is listed in Table 3.

\section{Future research}

The development of resistance in plants through conventional approaches is slow because of lack of knowledge on the genetic variation among plants against viruses. In this context, artificial doublestranded RNA (dsRNA) derived from the genome of virus offers a powerful way for resistance in host plants. RNAi-mediated silencing of viral genes such as replicase or coat protein leading to sequencespecific transcript degradation which can interfere with the viral replication process. The direct delivery of in vitro-transcribed dsRNA by mechanical inoculation interferes with the virus infection in a sequence specific manner. The dsRNA production is extremely low cost compared toregeneration of transgenic plants. This approach provides a reliable and potential tool for plant protection against virus diseases in future. 


\section{CONCLUSION}

The RNA silencing technology is a powerful tool, which facilitates the wider applications in the field of agriculture to develop improved crop varieties and astounding plant with a wider biotic and abiotic stress resistance. The tool has well been exploited for the effective management of plant virus diseases. However, the exogenous application/ delivery of RNAi methodology has to be standardized for effective suppression of plant viruses.

\section{REFERENCE}

Abdolhamid, A. S., Hedayati, S. S., Poor, R. H., Poor, S. S., Shiravi, S. and S.Madani. 2010. Application of RNA interference in plants. Plant Omics J., 3(3): 77-84

Abo, M. E. and A. A. Sy. 1998. Rice virus diseases: epidemiology and management strategies. J. Sustain. Agric., 11: 113-134.

Ali, I., Amin, I., Briddon, R. W. and S. Mansoor. 2013. Artificial microRNA-mediated resistance against the monopartite begomovirus Cotton leaf curl Burewala virus. Virol. J., 10: 231

Arun Kumar, N., Lakshminarasu, M., Zehr, U. B. and K. S. Ravi. 2008. Molecular characterization of Tobacco streak virus causing soybean necrosis in India. Indian J. of Biotechnol., 7: 214-217.

Asad, S., Haris, W. A., Bashir, A., Zafar, Y., Malik, K. A., Malik, N. N. and C. P. Lichtenstein. 2003. Transgenic tobacco expressing geminiviral RNAs are resistant to the serious viral pathogen causing cotton leaf curl disease. Arch. Virol., 148: 23412352.

Azevedo, J., Garcia, D., Pontier, D., Ohnesorge, S., Yu, A., Garcia, S., Braun, L., Bergdoll, M., Hakimi, M. A., Lagrange, T. and O. Voinnet. 2010. Argonaute quenching and global changes in dicer homeostasis caused by a pathogen-encoded GW repeat protein. Genes Dev., 24: 904-915

Bag, S., Singh, R. S. and R. K. Jain. 2007. Agrobacterium mediated transformation of groundnut with coat protein gene of Tobacco streak virus. Ind. J. Virol., 18(2): 65-69.

Bartel, D. P. 2004. MicroRNAs: genomics, biogenesis, mechanism, and function. Cell, 116(2): 281-297.

Baulcombe, D. 2004. RNA silencing in plants. Nature, 431: 356-63.

Baulcombe, D. C. 2002. Viral suppression of systemic silencing. Trends in Microbiology, 10:306-308.

Baumberger, N. and D. C. Baulcombe. 2005. Arabidopsis ARGONAUTE1 is an RNA slicer that selectively recruits microRNAs and short interfering RNAs. Proc. Natl Acad. Sci. USA, 102: 11928-11933.

Baumberger, N., Hsui Tsai, C., Lie, M., Havecker, E. and D. C. Baulcombe.2007. The Polerovirus silencing suppressor PO targets ARGONAUTE proteins for degradation. Curr. Biol., 17: 1609-1614

Beachy, R. N. 1986. Coat protein mediated resistance to Tobacco mosaic virus: Discovery mechanisms and exploitation. Philos. Trans. R. Soc. Lond. Biol. Sci., 354: 659-664.

Beck, D. L., Van Dolleweerd, C. J., Lough, T. J., Balmori, E., Voot, D. M., Andersen, M. T., O'Brien, I. E. W. and R. L. S. Forster. 1994. Disruption of virus movement confers broad-spectrum resistance against systemic infection by plant viruses with a triple gene block. Proc. Nat. Acad. of Sci. USA, 91:10310-10314.

Bernstein, E., Caudy, A. A., Hammond, S. M. and G. H. Hannon. 2001. Role for a bidentate ribonuclease in the initiation step of RNA interference. Nature, 409: 363-366.

Bonfim, K., Faria, J. C., Nogueira, E. O. P. L., Mendes, E. A., and F. J. L. Aragao. 2007. RNAi-mediated resistance to Bean golden mosaic virus in genetically engineered common bean (Phaseolus vulgaris). Mol. Plant-Microbe Interact.,20(6): 717-726.

Bortolamiol, D.Pazhouhandeh, M., Marrocco, K., Genschik, P. andV. Z. Graff.2007. The Polerovirus F box protein PO targets ARGONAUTE1 to suppress RNA silencing. Curr. Biol.,17: 1615-1621.

Bruun Rasmussen, M., Madsen, C. T., Jessing, S. and M. Albrechtsen. 2007. Stability of Barley stripe mosaic virus-induced gene silencing in barley. Mol. Plant Microbe Interact., 20: 1323-1331.

Burch-Smith, T. M., Anderson, J. C., Martin, G. B. and S. P. Dinesh-Kumar. 2004. Applications and advantages of virus-induced gene silencing for gene function studies in plants. The Plant J., 39(5): 734-746.

Burgyan, J. and Z. Havelda. 2011. Viral suppressors of RNA silencing. Tren. in Plant Sci., 16(5): 265-272.

Chen, T. Y., Pai, H., Hou, L. Y., Lee, S. C., Lin, T. T., Chang, C. H., Hsu, F. C., Hsu, Y. H. and N. S. Lin. 2019. Dual resistance of transgenic plants against Cymbidium mosaic virus and Odontoglossum ringspot virus. Scientific Rep.,9: 10230.

Chen, Y. K., Lohuis, D., Goldbach, R. and M. Prins. 2004. High frequency induction of RNA-mediated resistance against Cucumber mosaic virus using inverted repeat constructs. Mol. Breed., 14: 215-226.

Cogoni, C., Irelan, J. T., Schumacher, M., Schmidhauser, T. J., Selker, E. U. and G. Macino. 1996. Transgene silencing of the al-1 gene in vegetative cells of Neurospora is mediated by a cytoplasmic effector and does not depend on DNA-DNA interactions or DNA methylation. The EMBO Journal, 15(12): 3153-3163.

Constantin, G. D., Krath, B. N., MacFarlane, S. A., Nicolaisen, M., Johansen, I. E. and O. S. Lund. 2004.Virus-induced gene silencing as a tool for functional genomics in a legume species. Plant J., 40: 622-631.

Cooper, B., Lapidot, M., Heick, J. A., Allan Dodds, J. and R. N. Beachy. 1995. A defective movement protein of TMV in transgenic plants confers resistance to multiple viruses whereas the functional analog increases susceptibility. Virology, 206: 307-313.

Csorba, T., Bovi, A., Dalmay, T. and J. Burgyan. 2007. The p122 subunit of Tobacco mosaic virus replicase is 
a potent silencing suppressor and compromises both small interfering RNA- and microRNA-mediated pathways. J. Virol., 81: 11768-11780

Csorba, T., Lozsa, R., Hutvagner, G. and J. Burgyan. 2010. Polerovirus protein $\mathrm{PO}$ prevents the assembly of small RNA-containing RISC complexes and leads to degradation of ARGONAUTE1. The Plant J., 62(3): 463-472.

Dasgupta, I., Malathi, V. G. and S. K. Mukherjee. 2003. Genetic engineering for virus resistance. Curr. Sci., 84: 341-354.

Deleris, A. Bartolome, J. G., Bao, J., Kasschau, K. D., Carrington, J. C. and O. Voinnet. 2006. Hierarchical action and inhibition of plant Dicer-like proteins in antiviral defense. Science, 313: 68-71

Diaz Pendon, J. A., Li, F., Li, W. X. and S. W. Ding. 2007. Suppression of antiviral silencing by Cucumber mosaic virus $2 \mathrm{~b}$ protein in Arabidopsis is associated with drastically reduced accumulation of three classes of viral small interfering RNAs. Plant Cell, 19(6): 2053-2063

Ding, S. W. and O. Voinnet. 2007. Antiviral immunity directed by small RNAs. Cell, 130(3): 413-426.

Ding, X. S., Schneider, W. L., Chaluvadi, S. R., RoufMian, R. M. and R. S. Nelson. 2006. Characterization of a Brome mosaic virus strain and its use as a vector for gene silencing in monocotyledonous hosts. Mol. Plant Microbe Interact., 19: 1229-1239.

Duan, C. G., Fang, Y. Y., Zhou, B. J., Zhao, J. H., Hou, W. N., Zhu, H., Ding, S. W. and H. S. Guo. 2012. Suppression of Arabidopsis ARGONAUTE1-mediated slicing, transgene-induced RNA silencing, and DNA methylation by distinct domains of the Cucumber mosaic virus $2 b$ protein. The Plant Cell, 24(1): 259-274.

Elayabalan, S., Kalaiponmani, K., Subramaniam, S., Selvarajan, R., Panchanathan, R., Muthuvelayoutham, R. Kumar, K. K. and P. Balasubramanian. 2013. Development of Agrobacterium-mediated transformation of highly valued hill banana cultivar Virupakshi (AAB) for resistance to BBTV disease. World J. Microbiol. Biotechnol.,29: 589-596.

Elayabalan, S., Subramaniam, S. and R. Selvarajan. 2017. Construction of BBTV rep gene RNAi vector and evaluate the silencing mechanism through injection of Agrobacterium tumefaciens transient expression system in BBTV infected hill banana plants cv. Virupakshi (AAB). Indian J. of Nat. Sci., 7(42): 12395-12403

English, J. J., Mueller, E. and D. C. Baulcombe. 1996. Suppression of virus accumulation in transgenic plants exhibiting silencing of nuclear genes. Plant Cell, 8: 179-188.

Faria, J., Aragao, F., Souza, T., Quintela, E., Kitajima, E. and S. Ribeiro. 2016. Golden mosaic of common beans in Brazil: management with a transgenic approach. APSnet Feat. https://doi.org/10.1094/ APSFeature-2016-10

Fire, A., Xu, S., Montgomery, M. K., Kostas, S. A., Driver, S. E. and C. C. Mello. 1998. Potent and specific genetic interference by double-stranded RNA in Caenorhabditis elegans. Nature, 391: 806-811.
Fofana, I. B., Sangare, A., Collier, R., Taylor, C. andC. M. Fauquet. 2004. A Gemini virus induced gene silencing system for gene function validation in cassava. Plant Mol. Biol., 56: 613-624.

Fraser, A., Kamath, J. G., Zipperten, R. S., Campos, P., Sohrmann, M. M. and J. Ahringer. 2000. Functional genomic analysis of $C$. elegans chromosome I by systemic RNA interference. Nature, 408: 325-330.

Fusaro, A. F., Correa, R. L., Nakasugi, K., Jackson, C., Kawchuk, L., Vaslin, M. F. and Waterhouse, P. M. 2012. The Enamovirus PO protein is a silencing suppressor which inhibits local and systemic RNA silencing through AG01 degradation. Virology, 426(2): 178-187.

Gogoi, A., Kaldis, A., Dasgupta, I., Borah, B. K. and A. Voloudakis. 2019. Sense and antisense-mediated resistance against Sri Lankan cassava mosaic virus (SLCMV) in Nicotiana benthamiana. Biol. Plantarum, 63: $455-464$

Golemboski, D. B., Lomonossoff, G. P. and M. Zaitlin. 1990. Plants transformed with a Tobacco mosaic virus non-structural gene sequence are resistant to the virus. Proc. Nat. Acad. Sci., USA, 87: 6311-6315.

Gonczy, P., Echerverri, C., Oegema, K., Coulron, A., Jones, S. J. M., Copley, R. R., Duperon, J., Oegema, J., Brehm, M., Carrin, E., Hannak, E., Kirkham, M., Pichler, S., Flohrs, K., Gossen, A., Liedel, S., Alleaume, A. M., Martin, C., Ozlu, N., Bork, P. and A. A. Hyman. 2000. Functional genomic analysis of cell division in $C$. elegans with RNAi of genes on chromosome III. Nature, 408: 331-335.

Gonsalves, D., Gonsalves, C., Ferriera, S., Pitz K., Fitch, M., Manshardt, R. and J. Slightom. 2004. Transgenic virus resistant papaya: from hope to reality for controlling Papaya ringspot virus in Hawaii. APSnet. Feat. https://doi.org/10.1094/ APSnetFeature-2004-0704

Grishok, A., Tabara, H. and C. C. Mello. 2000. Genetic requirements for inheritance of RNAi in C. elegans. Science, 287: 2494-2497.

Guo, H. S. and S. W. Ding. 2002. A viral protein inhibits the long range signaling activity of the gene silencing signal. EMBO J., 21: 398-407

Guo, H. S., Lopez-Moya, J. J. and J. A. Garcia. 1999. Mitotic stability of infection-induced resistance to Plum pox potyvirus associated with transgene silencing and DNA methylation. Mol. Plant Microbe Interact., 12: 103-111

Guo, J., Gao, S., Lin, Q., Wang, H., Que, Y. and L. Xu. 2015. Transgenic sugarcane resistant to Sorghum mosaic virus based on coat protein gene silencing by RNA interference. BioMed Res. Int., 86: 1-9.

Guo, S. and K. J. Kemphues. 1995. par-1, a gene required for establishing polarity in c. elegans embryos, encodes a putative Ser/Thr kinase that is asymmetrically distributed. Cell, 81: 611-620.

Haas, G., Azevedo, J., Moissiard, G., Geldreich, A., Himber, G., Bureau, M., Fukuhara, T., Keller, M. and O. Voinnet. 2008. Nuclear import of CaMV P6 is required for infection and suppression of the RNA silencing factor DRB4. EMBO J., 27: 2102-2112

$$
107|10-12| 13
$$


Hamilton, A. J. and Baulcombe, D. C. 1999. A species of small antisense RNA in post-transcriptional gene silencing in plants. Science, 286: 950-952.

Hammond, S. M., Bernstein, E., Beach, D. and G. J. Hannon. 2000. RNA-directed nuclease mediates post-transcriptional gene silencing in Drosophila cells. Nature, 404: 293-296.

Hannon, G. J. 2002. RNA interference. Nature, 418: 244-251

Heinlein, M. 2015. Plant virus replication and movement. Virology, 479: 657-671.

Helliwell, C. and P. Waterhouse, 2003. Constructs and methods for high-throughput gene silencing in plants. Methods, 30: 289-295.

Hellwald, K. H. and P. Palukaitis. 1995. Viral RNA as a potential target for two independent mechanisms of replicase-mediated resistance against Cucumber mosaic virus. Cell, 83: 937-946.

Horiguchi, G. 2004. RNA silencing in plants: a shortcut to functional analysis. Differentiation, 72: 65-73.

Hu, Q., Niu, Y., Zhang, K., Liu, Y. and X. Zhou. 2011. Virus-derived transgenes expressing hairpin RNA give immunity to Tobacco mosaic virus and Cucumber mosaic virus. Virol. J., 8: 41.

Jada, B., Soitamo, A. J., Siddiqui, S. A., Murukesan, G., Aro, E. M., Salakoski, T. and K. Lehto, 2014. Multiple different defense mechanisms are activated in the young transgenic tobacco plants which express the full length genome of the Tobacco Mosaic Virus, and are resistant against this virus. PLoS One, 9(9): e107778.

Jagtap, G. P., Jadhav, T. H. and D. Utpal, 2012. Occurrence, distribution and survey of Tobacco streak virus (TSV) of cotton. Sci. J. Crop Sci., 1(1): 16-19

Jain, R. K., Bag, S. and L. P. Awasthi. 2005. First report of natural infection of Capsicum annuum by Tobacco streak virus in India. Plant Pathol., 54: 257.

Jain, R. K., Vemana, K., and S. Bag, 2008. Tobacco streak virus an emerging virus in vegetable crops, characterisation, diagnosis and management of plant viruses. Pages 203-212 in: Volume-3. Vegetable and Pulse Crops. Stadium press LLC, Texas, USA.

Jia, R., Zhao, H., Huang, J., Kong, H., Zhang, Y., Guo, J., Huang, Q., Guo, Y., Wei, Q., Zuo, J., Zhu, Y. J., Peng, M. and A. Guo. 2017. Use of RNAi technology to develop a PRSV-resistant transgenic papaya. Scientific Rep., 7: 12636.

Jones, A. L. Thomas, C. L. and A. J. Maule. 1998. De novo methylation and co-suppression induced by a cytoplasmically replicating plant RNA virus. EMBO J., 17: 6385-6393

Jones, L., Hamilton, A. J., Voinnet, O., Thomas, C. L., Maule, A. J. and D. C. Baulcombe. 1999. RNADNA interactions and DNA methylation in posttranscriptional gene silencing. Plant Cell, 11: 2291-2302

Kalantidis, K., Psaradakis, S., Tabler, M. and M. Sagris. 2002. The occurrence of CMV specific short RNAs in transgenic tobacco expressing virus-derived double-stranded RNA is indicative of resistance to the virus. Mol. Plant Microbe Interact., 15: 826-833.

Kamachi, S., Mochizuki, A., Nishiguchi, M. and Y. Tabei. 2007. Transgenic Nicotiana benthamianaplants resistant to Cucumber green mottle mosaic virus based on RNA silencing. Plant Cell Rep., 26: 1283-1288.

Kanazawa, A., Inaba, J. I.,Shimura, H., Otagaki, S., Tsukahara, S., Matsuzawa, A., Kim, B. M., Goto, K. and C. Masuta. 2011. Virus-mediated efficient induction of epigenetic modifications of endogenous genes with phenotypic changes in plants. Plant J., 65: 156-168

Kaniewski, W. K. and P. E. Thomas. 2004. The potato story. AgBio Forum, 7: 41-46

Kataya, A., Suliman, M., Kalantidis, K. and I. Livieratos, 2009. Cucurbit yellow stunting disorder virus p25 is a suppressor of post-transcriptional gene silencing. Virus Res., 145:48-53.

Kawazu, Y., Ryoi, F. and N. Yuji, 2009. Transgenic resistance to Mirafiori lettuce virus in lettuce carrying inverted repeats of the viral coat protein gene. Transgenic Res., 18: 113-120.

Konakalla, N. C., Kaldis, A., Masarapu, H. and A. E. Voloudakis. 2019. Topical application of double stranded RNA molecules deriving from Sesbania mosaic virus (SeMV) CP and MP genes protects Sesbania plants against SeMV. Eur. J. Plant Pathol. doi.org/10.1007/s10658-019-01821-z

Krubphachaya, P., Jurick, M. and S. Kertbundi. 2007. Induction of RNA-mediated resistance to Papaya Ringspot Virus Type W. J. Biochem. Mol. Bio., 40: 404-411.

Kumar, A., Kumar, V., Krishnan, V., Hada, A., Marathe, A., Parameswaran C., Jolly, M. and A. Archana Sachdev. 2019. Seed targeted RNAi-mediated silencing of GmMIPS1 limits phytate accumulation and improves mineral bioavailability in soybean. Scientific Rep., 9: 7744.

Kumar, S., Tanti, B., Patil, B. L., Mukherjee, S. K. andL. Sahoo. 2017. RNAi-derived transgenic resistance to Mungbean yellow mosaiclndia virus in cowpea. PLoS One, 12(10): e0186786.

Kunkalikar, S. R., Poojari, S., Arun, B. M., Rajagopalan, P. A., Chen, T. C., Yeh, S. D., Naidu, R. A., Zehr, U. B. and K. S. Ravi. 2011. Importance and genetic diversity of vegetable-infecting tospoviruses in India. Virology, 101(3): 367-376

Kunkalikar, S. R., Sudarsana, P., Rajagopalan, P., Zehr, U. B. and K. S. Ravi 2010. Biological and molecular characterization of Capsicum chlorosis virus infecting chilli and tomato in India. Arch. Virol., 55(7): 1047-57.

Kusaba, M. 2004. RNA interference in crop plants. Current Opinion in Biotechnology, 15(2): 139-143.

Ladhalakshmi, D., Ramiah, M., Ganapathy, T., Reddy, M. K., Salaheddin, K., Merin, B. and A. Kamalakannan. 2006. First report of the natural occurrence of

$107|10-12| 14$ 
Tobacco streak virus on blackgram (Vigna mungo). Plant Pathology, 55: 569.

Lakatos, L., Csorba, T., Pantaleo, V., Chapman, E. J., Carrington, J. C., Liu, Y. P., Dolja, V. V., Calvino, L. F., Lopez-Moya, J. J. and J. Burgyan, 2006. Small RNA binding is a common strategy to suppress RNA silencing by several viral suppressors. $E M B O$ J., 25: 2768-2780

Lange, M., Yellina, A. L., Orashakova, S. and A. Becker. 2013. Virus-induced gene silencing (VIGS) in plants: an overview of target species and the virusderived vector systems. In: Virus-Induced Gene Silencing (pp. 1-14). Humana Press, Totowa, NJ.

Lapidot, M., Gafny, R., Ding, B., Wolf, S., Lucas, W. J. and R. N. Beachy. 1993. A dysfunctional movement protein of Tobacco mosaic virus that partially modifies the plasmodesmata and limits virus spread in transgenic plants. Plant J., 4: 959-970.

Lee, C. C., Wang, J. W., Leu, W. M., Huang, Y. T., Huang, Y. W., Hsu, Y. H. and M. Meng, 2019. Proliferating cell nuclear antigen suppresses RNA replication of Bamboo mosaic virus through an interaction with the viral genome. J.Virol., 93: e00961-19.

Lee, Y. S. and R. W. Carthew. 2003. Making a better RNAi vector for Drosophila: Use of intron spacers. Methods, 30: 322-329.

Legg, J. P. and J. M. Thresh, 2000. Cassava mosaic virus disease in East Africa: a dynamic disease in a changing environment. Virus Res.,71: 135-149.

Li, L., Cheng, G., Biao, W., Tong, Z., Yang, L., Yu-hua, D., Wen, H., Chun, L. and W. Xi-feng. 2016. RNAi-mediated transgenic rice resistance to Rice stripe virus. J. Integr. Agric., doi.10.1016/s20953119(16)61369-2

Lindbo, J. A., Silva-Rosales, L., Proebsting, W. M. and W. G. Dougherty. 1993. Induction of a highly specific antiviral state in transgenic plants: implications for regulation of gene expression and virus resistance. Plant Cell,5: 1749-1759.

Lozsa, R., Csorba, T., Lakatos, L. and J. Burgyan. 2008. Inhibition of $\mathbf{3 0}$ modification of small RNAs in virus-infected plants require spatial and temporal co-expression of small RNAs and viral silencing suppressor proteins. Nucleic Acids Res., 36: 4099-4107

Lu, R., Folimonov, A., Shintaku, M., Li, W. X., Falk, B. W., Dawson, W. O. and S. W. Ding. 2004. Three distinct suppressors of RNA silencing encoded by a 20-kb viral RNA genome. Proc. Nat. Acad. Sci., 101(44): 15742-15747.

Lu, R., Martin-Hernandez, A. M., Peart, J. R., Malcuit, I. and D. C. Baulcombe. 2004. Virus-induced gene silencing in plants. Methods, 30(4): 296-303.

Luna, A. P., Morilla, G., Voinnet, O. and E. R. Bejarano. 2012. Functional analysis of gene-silencing suppressors from tomato yellow leaf curl disease viruses. Mol.Plant-Micro. Inter., 25(10): 1294 1306.

Malyshenko, S. I., Kondakova, O. A., Nazarova, J. V., Kaplan, I. B., Taliansky, M. E. and J. G. Atabekov. 1993. Reduction of Tobacco mosaic virus accumulation in transgenic plants producing nonfunctional viral transport proteins. J. Gen. Virol., 74: 1149-1156.

Mayers, C. N., Palukaitis, P. and J. P. Carr. 2000. Subcellular distribution analysis of the Cucumber mosaic virus 2b protein. J. Gen. Virol., 81: 219-226

Meister, G. and T. Tuschl. 2004. Mechanisms of gene silencing by double stranded RNA. Nature, 431: 343-349.

Merai, Z., Kerenyi, Z., Kertesz, S., Magna, M., Lakatos, L. and D. Silhavy. 2006. Double-stranded RNA binding may be a general plant RNA viral strategy to suppress RNA silencing. J. Virol., 80: 5747-5756

Merai, Z., Kerenyi, Z., Molnar, A., Barta, E., Valoczi, A., Bisztray, G., Havelda, Z., Burgyan, J. and D. Silhavy. 2005. Aureusvirus P14 is an efficient RNA silencing suppressor that binds double-stranded RNAs without size specificity. J. Virol., 79: 7217-7226

Molnar, A., Csorba, T., Lakatos, L., Varallyay, E., Lacomme, C. and J. Burgyan, 2005. Plant virus-derived small interfering RNAs originate predominantly from highly structured single-stranded viral RNAs. J. Virol., 79: $7812-818$

Mundembe, R., Matibiri, A. and I. Sithole Niang. 2009. Transgenic plants expressing the coat protein gene of Cowpea aphid-borne mosaic potyvirus predominantly convey the delayed symptom development phenotype. African J. Biotechnol., 8(12): 2682-2690.

Muralidharan, K., Krishnaveni, D., Rajarajeswari, N. and A. Prasad. 2003. Tungro epidemics and yield losses in paddy fields in India. Current Science, 85(8): 1143-1147.

Nahid, N., Amin, I., Briddon, R. W. and S. Mansoor. 2011. RNA interference-based resistance against a legume mastrevirus. Virol. J., 8: 499

Napoli, C., Lemieux, C. and R. Jorgensen. 1990. Introduction of chimeric chalcone synthase gene into Petunia results in reversible co-suppression of homologous genes in trans. Plant Cell, 2: 279-289.

Naylor, M., Reeves, J., Cooper, J. I., Edwards, M. L. andH. Wang. 2007. Construction and properties of a gene-silencing vector based on Poplar mosaic virus (genus Carlavirus). J. Virol. Methods, 124: 27-36.

Nejidat, A. and R. N. Beachy. 1990. Transgenic tobacco plants expressing a coat protein gene of Tobacco mosaic virus are resistant to some other tobamoviruses. Mol. Plant Micro. Interact., 3: 247-251.

Niu, S., Wang, B., Guo, X., Yu, J., Wang, X., Xu, K., Zhai, Y., Wang, J. and Z. Liu. 2009. Identification of two RNA silencing suppressors from Banana bunchy top virus. Arch.Virol., 154(11): 1775.

Nomura, K., Ohshima, K., Anai, T., Uekusa, H. and N. Kita. 2004. RNA silencing of the introduced coat protein gene of Turnip mosaic virus confers broadspectrum resistance in transgenic Arabidopsis. Phytopath., 94: 730-736.

Ntui, V.O., Kong, K., Khan, R.S., Igawa, T., Janavi, G.J., 
Rabindran, R., Nakamura, I. and M. Mii. 2015. Resistance to Sri Lankan cassava mosaic virus (SLCMV) in genetically engineered cassava cv. KU50 through RNA silencing. PLoSOne, 10(4): e0120551.

Ntui, V., Kong, K., Azadi, P., Khan, R., Chin, D., Igawa, T., Mii, M. and I. Nakamura. 2014. RNAi-mediated resistance to Cucumber mosaic virus (CMV) in genetically engineered tomato. American J. Plant Sci., 5: 554-572.

Ogita, S., Uefuji, H., Yamaguchi, Y., Koizumi, N. and H. Sano. 2003. Producing decaffeinated coffee plants. Nature, 423: 823.

Peele, C., Jordan, C. V., Muangsan, N., Turnage, M., Egelkrout, E., Eagle, P., Hanley-Bowdoin, L. and D. Robertson. 2001. Silencing of meristematic gene using geminivirus-derived vectors. Plant J., 27: 357-366

Peng, J. C., Chen, T. C., Raja, J.A.J. Yang, C. F., Chien, W. C., Lin, C.H., Liu, F. L., Wu, H. W. and S. D. Yeh. 2014. Broad-spectrum transgenic resistance against distinct Tospovirus species at the genus level. PLoS One, 9(5): e96073

Pereira, T. C. and I. L. Cendes. 2013. Medical applications of RNA interference (RNAi). BMC Proceedings, 7(Suppl. 2): K21

Pflieger, S., Blanchet, S., Camborde, L., Drugeon, G., Rousseau, A., Noizet, M., Planchais, S. and I. Jupin. 2008. Efficient virus-induced gene silencing in Arabidopsis using a 'one-step' TYMV-derived vector. Plant J., 56: 678-690.

Pottash, A. E., Kuffner, C., Noonan-Shueh, M. and M. J. Steven. 2019. Protein-based vehicles for biomimetic RNAi delivery. J. Biol. Eng., 13: 19.

Pradeep, K., Satya, V. K., Selvapriya, M., Vijayasamundeeswari, A., Ladhalakshmi, D., Paranidharan, V., Rabindran, R., Samiyappan, R., Balasubramanian, P. and R. Velazhahan. 2012. Engineering resistance against Tobacco streak virus (TSV) in sunflower and tobacco using RNA interference. Biologia Plant., 56: 735-741.

Raj, S. K., Rachana Singh, Pandey, S. K. and B. P. Singh. 2005. Agrobacterium-mediated tomato transformation and regeneration of transgenic lines expressing Tomato leaf curl virus coat protein gene for resistance against TLCV infection. Curr. Sci., 88 (10): 1674-1679.

Rajamanickam, S., Chandrasekar, G. and G. Karthikeyan, 2015a. Coat protein mediated resistance against Tobacco streak virus in Nicotiana tabacum L. through RNA silencing. The Bioscan, 10(4): 1787 1793

Rajamanickam, S. Raveendran, M., and G. Karthikeyan.2015b. Conserved sequence of replicase gene mediated resistance in Nicotiana tabacum L. cv Abirami through RNA silencing. Eur. J. of Plant Pathol., 142(4): 865-874

Ramesh, S. V., Mishra, A. K., and S. Praveen. 2007. Hairpin RNA-mediated strategies for silencing of Tomato leaf curl virus AC1 and AC4 genes for effective resistance in plants. Oligonucleotides, 17(2): 251-257.
Ramiah, M., Bhat, A. I., Jain, R. K., Pant, R. P., Ahlawat, Y. S., Prabhakar, K. and A. Verma. 2001. Partial characterization of an isometric virus causing sunflower necrosis disease. Indian Phytopath., 54: 246-250.

Reddy, A. S., Prasada Rao, R. D. V. J., Thirumala Devi, K., Reddy, S. V., Mayo, M. A., Roberts, I., Satyanarayana, T., Subramaniam, K., and D. V. R. Reddy. 2002. Occurrence of Tobacco streak virus on Peanut (Arachis hypogaea) in India. Plant Dis., 86: 173-178.

Renovell, A., Vives, M. C., Ruiz-Ruiz, S., Navarro, L., Moreno, P. and J. Guerri. 2012. The Citrus leaf blotch virus movement protein acts as silencing suppressor. Virus genes, 44(1): 131-140.

Ruiz M. T., Voinnet, O. and D. C. Baulcombe. 1998. Initiation and maintenance of virus induced gene silencing. Plant Cell, 10: 937-946.

Saker, M. M. 2003. Production of biosafe transgenic potato plants with coat protein gene for Potato virus Y. Arab J. Biotech., 6(1): 125-138.

Sasaya, S., Nagaoka, E. N., Saika, H., Aoki, H., Hiraguri, A., Netsu, O., Uehara-lchiki, T., Onuki, M., Toki, S., Saito, K., and O. Yatou. 2014. Transgenic strategies to confer resistance against viruses in rice plants. Front. in Microbiol., 4: 409

Schnettler, E., Hemmes, H., Huismann, R., Goldbach, R., Prins, M. and R. Kormelink. 2010. Diverging affinity of tospovirus RNA silencing suppressor proteins, NSs, for various RNA duplex molecules. J.Virol., 84(21): 11542-11554.

Schwarz, D. S., Hutvagner, G., Du, T., Xu, Z., Aronin, N. andP. D. Zamore. 2003. Asymmetry in the assembly of the RNAi enzyme complex. Cell, 115(2): 199-208.

Scorza, R., Callahan, A., Dardick, C., Ravelonandro, M., Polak, J., Malinowski, T., Zagrai, I., Cambra, M. and I. Kamenova. 2013. Genetic engineering of Plum pox virus resistance: 'Honey Sweet' plumfrom concept to product. Plant Cell Tissue Organ. Cult.,115: 1-12

Segal G., Song R. and J. Messing. 2003. A new opaque variant of maize by a single dominant RNA-interferenceinducing transgene. Genetics, 165: 387-397

Senthil Kumar, M. and K. S. Mysore. 2011. Virusinduced gene silencing can persist for more than 2 years and also be transmitted to progeny seedlings in Nicotiana benthamiana and tomato. Plant Biotechnol. J., 9: 797-806

Senthil Kumar, M and K. S. Mysore. 2014. Tobacco rattle virus-based virus-induced gene silencing in Nicotiana benthamiana. Nat. Prot.,9(7): doi 10.1038/nprot.2014.092

Senthilraja, C., Gurivi Reddy, M., Rajeswaran, J., Kokiladevi, E. andR. Velazhahan. 2018. RNA interference-mediated resistance to Tobacco streak virus in transgenic peanut. Australasian Plant Pathol. https://doi.org/10.1007/s13313018-0549-9

Shekhawat, U. K. S., Ganapathi, T. R. and B. Hadapad. 2012. Transgenic banana plants expressing small interfering RNAs targeted against viral replication 
initiation gene display high-level resistance to Banana bunchy top virus infection. J. Gen.Virol., 93: 1804-1813

Shepherd, D. N., Mangwende, T., Martin, D. P., Bezuidenhout, M., Kloppers, J. F., Carolissen, C. H., Monjane, A. L., Rybicki, E. P. and J. A. Thomson. 2007. Maize streak virus-resistant transgenic maize: a first for Africa. Plant Biotec. J., 5: 1-9.

Sivaprasad, Y., Bhaskara Reddy, B. V., Rekha Rani, K., Raja Reddy, K. and D. V. R. Sai Gopal. 2010. First report of Tobacco streak ilarvirus infecting onion (Allium cepa). New Dis. Rep., 22: 17.

Smith, N. A., Singh, S. P., Wang, M. B., Stoutjesdijk, P. A., Green, A. G. and P. M. Waterhouse. 2000. Total silencing by intron spliced hairpin RNAs. Nature, 147: 19-320.

Soosaar, J. L. M., Burch-Smith, T. M. and S. DineshKumar. 2005. Mechanisms of plant resistance to viruses. Nat. Rev. Microbiol., 3: 789-798.

Suganyadevi, M. 2019. Engineering Groundnut bud necrosis virus resistance through RNA silencing technology. Tamil Nadu Agricultural University, Coimbatore.

Sushmitha, C. and S. K. Bhat. 2014. Pepper vein banding virusan over view. Int. J. Sci.Res., 3(6): 30-31

Taha, O., Farouk, I., Abdallah, A. and N. A. Abdallah. 2016. Use of posttranscription gene silencing in squash to induce resistance against the Egyptian isolate of the Squash leaf curl virus. Int. J. Genomics, 2016: e6053147.

Tao, X. and X. Zhou. 2004. A modified viral satellite DNA that suppresses gene expression in plants. Plant J., 38: 850-860.

Thottapilly, G., Thresh, J., Calvert, L. A. and S. Winter. 2003. Cassava. In: Virus and virus-like diseases of major crops in developing countries, [ed. by Loebenstein, G., Thottapilly, G.]. Dordrecht, Netherlands: Kluwer Academic Publishers. 107165.

Tomari, Y. and P. D. Zamore. 2005. Perspective: machines for RNAi. Genes and Dev., 19: 517-529

Tougou, M., Furutani, N., Yamagishi, N., Shizukawa, Y., Takahata, Y. and S. Hidaka. 2006. Development of resistant transgenic soybeans with inverted repeat-coat protein genes of Soybean dwarf virus. Plant Cell Rep., 25:1213-1218.

Tricoli, D. M., Carney, K. J., Russell, P. F., McMaster, J. R., Groff, D. W., Hadden, K. C., Himmel, P. T., Hubbard, J. P., Boeshore, M. L and H. D. Quemada. 1995. Field evaluation of transgenic squash containing single or multiple virus coat protein gene constructs for resistance to Cucumber mosaic virus, Watermelon mosaic virus 2, and/or Zucchini yellow mosaic virus. Bio-Technol., 13: 1458-65.

Trinks, D., Rajeswaran, R., Shivaprasad, P. V., Akbergenov, R., Oakeley, E. J., Veluthambi, K., Hohn, T. and M. M. Pooggin. 2005. Suppression of RNA silencing by a geminivirus nuclear protein, AC2, correlates with transactivation of host genes. J. Virol., 79(4): 2517-2527.
Turnage, M.A., Muangsan, N., Peele, C.G. andD. Robertson. 2002. Geminivirus-based vectors for gene silencing in Arabidopsis. Plant J., 30: 107117.

Tyagi, H., Rajasubramaniam, S., Rajam, V. M. and I. Dasgupta. 2008. RNA-interference in rice against Rice tungro bacilliform virus results in its decreased accumulation in inoculated rice plants. Transgenic Res., 17: 897-904.

Valentine, T., Shaw, J., Blok, V. C., Phillips, M. S., Oparka, K. J. and C. Lacomme, 2004. Efficient virusinduced gene silencing in roots using a modified Tobacco rattle virus vector. Plant Physiol., 136(4): 3999-4009.

Van der Krol, A. R., Mur, L. A., de Lange, P., Mol, J. N. and A. R. Stuitje. 1990. Inhibition of flower pigmentation by antisense CHS genes: promoter and minimal sequence requirements for the antisense effect. Plant Mol. Biol., 14: 457-466.

Vance, V. and H. Vaucheret. 2001. RNA silencing in plants-defense and counter defense. Science, 292: 2277-2280.

Vargas, M., Garcia, B. M., Ruiz, J. R. D. and F. Tenllado. 2008. Transient expression of homologous hairpin RNA interferes with PVY transmission by aphids. Virology J., 5: 1-5.

Vargason, J., Szittya, G., Burgyan, J. and T. M. Tanka Hall. 2003. Size selective recognition of SiRNA by an RNA silencing suppressor. Cell, 115: 799-811

Vaucheret, H. 2008. Plant ARGONAUTES. Trends Plant Sci., 13: 350-358.

Vaucheret, H. and M. Fagard. 2001. Transcriptional gene silencing in plants: targets, inducers and regulators. Trends Genet., 17: 29-35.

Vinodkumar, S., Nakkeeran, S., Malathi, V. G., Karthikeyan, G., Amala Balu, P., Mohankumar, S. and P. Renukadevi, 2017. Tobacco streak virus: an emerging threat to cotton cultivation in India Phytoparasitica, 45: 729-743

Vogler, H., Akbergenov, R., Shivaprasad, P. V., Dang, V., Fasler, M., Kwon, M. O., Zhanybekova, S., Hohn, T. andM. Heinlein, 2007. Modification of small RNAs associated with suppression of RNA silencing by tobamovirus replicase protein. J. Virol., 81: 10379-10388

Voinnet, O. 2001. RNA silencing as a plant immune system against viruses. Trends Genet., 17: 449459.

Walsh H. A., Vanderschuren, H., Taylor, S. and M. E. C. Reya. 2019. RNA silencing of South African cassava mosaic virus in transgenic cassava expressing AC1/AC4 hp- RNA induces tolerance. Biotechnol. Rep., 24: e00383

Wang, M. B., Abbott, D. and P. M. Waterhouse. 2000. A single copy of a virus derived transgene encoding hairpin RNA gives immunity to Barley yellow dwarf virus. Mol. Plant Pathol., 1: 401-410.

Waterhouse, P. M., Graham, M. W. and M. B. Wang. 1998. Virus resistance and gene silencing in plants can be induced by simultaneous expression of sense and 
antisense RNA. Proc. Natl. Acad. Sci., 95:1395913964.

Watson, J. M., Fusaro, A. F., Wang, M. and P. M. Waterhouse. 2005. RNA silencing platforms in plants. FEBS Lett., 579: 5982-5987.

Wesley, V. S., Helliwell, C. A., Smith, N. A., Wang, M., Rouse, D. T., Liu, Q., Gooding, P. S., Singh, S. P., Abbott, D., Stoutjesdijk, P. A., Robinson, S. P., Gleave, A. P., Green, A. G. and P. M. Waterhouse. 2001. Construct design for efficient, effective and high throughput gene silencing in plants. Plant J., 27: 581-590.

Wu, Q., Wang, X. and S. W. Ding. 2010. Viral suppressors of RNA-based viral immunity: host targets. Cell Host Microbe, 8: 12-15

Xie, X., Song, Y., Liu, X, Wang, S., Zhu, S. and F. Wen. 2014. Different target genes and chimeric-gene hairpin structures affect virus resistance mediated by RNA silencing in transgenic tobacco. Biologia Plant., 58(3): $575-581$

Xie, Z., Johansen, L. K., Gustafson, A. M., Kasschau, K. D., Lellis, A. D., Zilberman, D., Jacobsen, S. E. and J. C. Carrington. 2004. Genetic and functional diversification of small RNA pathways in plants. PLoS Biology.,2: 642-652.

Yadav, J. S., Ogwok, E., Wagaba, H., Patil, B. L., Bagewadi, B., Alicai, T., Solis, E. G., Taylor, N. J. and C. M. Fauquet. 2011. RNAi-mediated resistance to Cassava brown streak Uganda virus in transgenic cassava. Mol. Plant Pathol., 12(7): 677-687

Yamagishi, N., Sasaki, S., Yamagata, K., Komori, S., Nagase, M., Wada, M., Yamamoto, T. and N. Yoshiwaka. 2011. Promotion of flowering and reduction of a generation time in apple seedlings by ectopical expression of the Arabidopsis thaliana FT gene using the Apple latent spherical virus vector. Plant Mol. Biol., 75: 193-204.

Yang, Y., Sherwood, T. A., Hiebert, C. P. and J. E. Polston. 2004. Use of Tomato yellow leaf curl virus (TYLCV) Rep gene sequences to engineer TYLCV resistance in tomato. Phytopath., 94: 490-496.

Ye, K. and D. J. Patel. 2005. RNA silencing suppressor p21 of Beet yellows virus forms an RNA binding octameric ring structure. Structure, 13(9): 13751384.

Young, B. A., Stenger, D. C., Qu, F., Morris, T. J., Tatineni, S. and R. French. 2012. Tritimovirus P1 functions as a suppressor of RNA silencing and an enhancer of disease symptoms. Virus Res., 163(2): 672-677.

Yu, B., Chapman, E. J., Yang, Z., Carrington, J. C. and X. Chen. 2006. Transgenically expressed viral RNA silencing suppressors interfere with microRNA methylation in Arabidopsis. FEBS Lett., 580: 3117-3120

Zaitlin, M., Anderson, J. M., Perry, K. L. M, Zhang, L. and P. Palukaitis. 1994. Specificity of replicasemediated resistance to Cucumber mosaic virus. Virology, 201: 200-205.

Zamore, P., Tuschl, T., Sharp, P. A. and D. Bartel. 2000. RNAi: Double-stranded RNA directs the ATP-dependent cleavage of mRNA at 21 to 23 nucleotide intervals. Cell, 101. 25-33.

Zhao, F., Lim, S., Igori, D., Yoo, R. H., Kwon,S. Y. and J. S. Moon. 2016. Development of Tobacco ringspot virus-based vectors for foreign gene expression and virus-induced gene silencing in a variety of plants. Virology, 492: 166-178. 